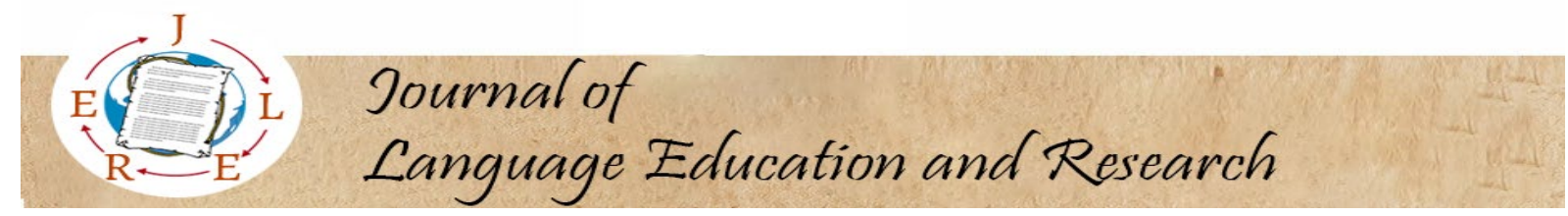

$7(2), 2021$

Journal of Language Education and Research

Research Article

\title{
Analysis of Pedagogical Texts Prepared for Academic Turkish as a Foreign Language in Terms of Academic Vocabulary
}

\author{
Burak TÜFEKÇIOĞLU *
}

\begin{tabular}{l}
\hline ARTICLE INFO \\
\hline Received 01.08.2021 \\
Revised form 22.09.2021 \\
Accepted 15.10.2021 \\
Doi:10.31464/jlere.983626
\end{tabular}

Keywords: vocabulary academic Turkish academic words academic Turkish teaching as a foreign language

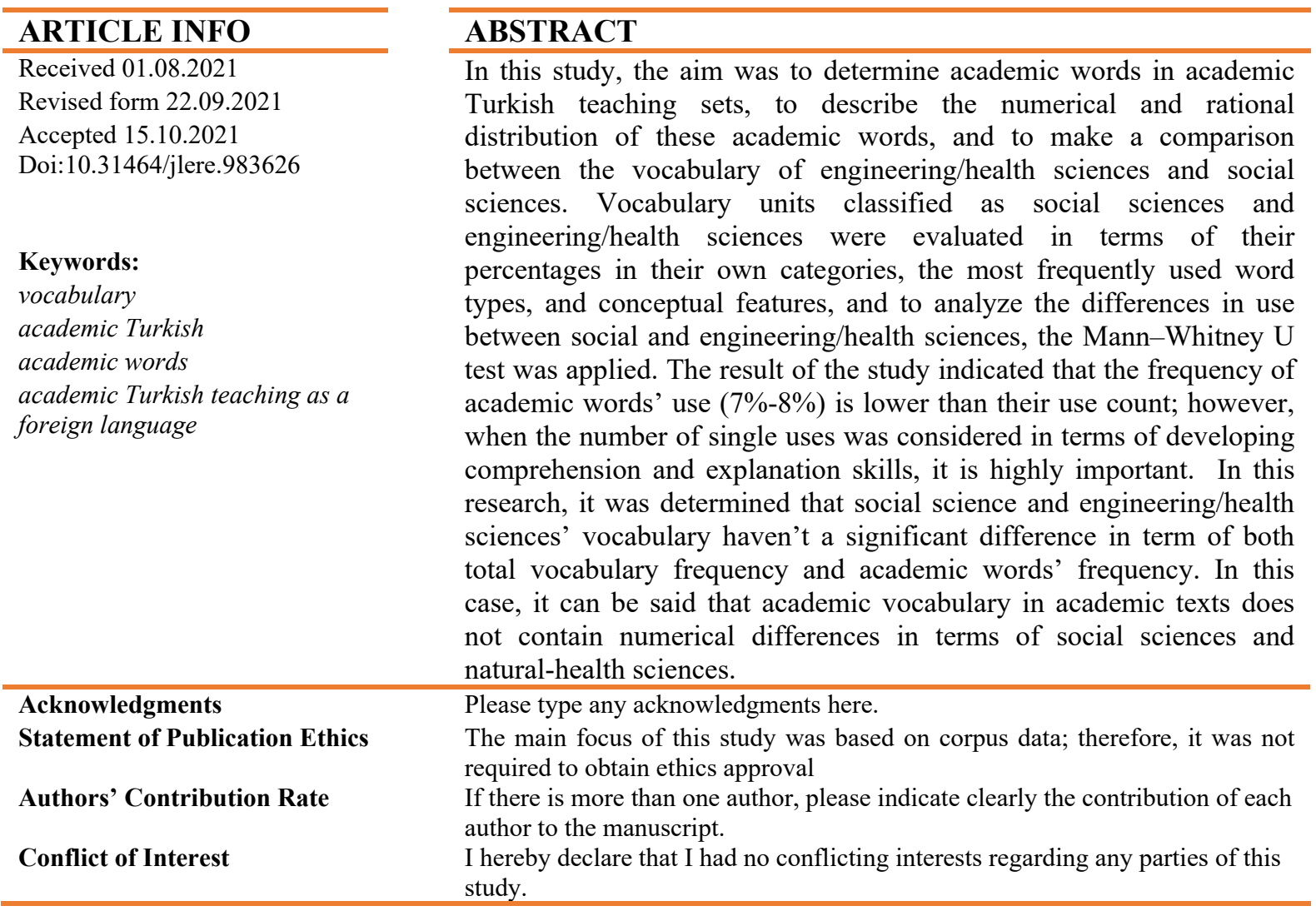

* Dr. Öğr. Üyesi, ORCID ID: https://orcid.org/0000-0002-8933-3850, Eskişehir Osmangazi Üniversitesi, Türkçe ve Sosyal Bilimler Eğitimi Bölümü, Türkçe Eğitimi Anabilim Dalı, burak.tufekcioglu@ogu.edu.tr 


\section{Introduction}

Words, as linguistic units, have a fundamental role in oral and written communication as they illustrate concepts. In this respect, vocabulary teaching is critical in foreign language teaching, the aim of which is to communicate in the target language (Alipoor \& Jadidi, 2016). It is a significant issue to decide which linguistic units will be accepted as words in word list development processes (Coxhead, 2000). However, defining words conceptually is not easy. For this reason, there are many definitions of words in the literature. It is seen that the word definitions in the literature are shaped according to the features and functions of the words in the language. In the word definitions created in terms of the features of the words, features such as the presence of spaces between them in the text and their having meanings are stated (Demir, 2017; Jackson, 2016; İmer, Kocaman \& Özsoy, 2013). It is known that words have certain limits in the language. However, in Turkish spelling, not every element with spaces, such as $\mathrm{mX}$, $\mathrm{dA}$, and ki, is considered a word (Demir, 2017). Thus, while defining a word, the function of the word in the language is taken into account and a word definition is created according to that function. From a semantic/lexicographic point of view, the word is defined as the smallest independent meaning carrier that is coded in dictionaries (Demir \& Y1lmaz, 2012). Another definition describes it as "new language units in linguistic operations such as inflection, derivation, or combining, etc., which has the characteristics of a head word in dictionaries, and which are definite or widespread forms of writing and pronunciation" (Y1lmaz, 2014). In both definitions, it is stated that the word has a headword feature with definitions in dictionaries. In the present research, according to the Turkish Language Institution Current Turkish Dictionary (CTD), the units defined as head words are accepted as words.

The main purpose of foreign language teaching is to enable the learner to communicate in the target language by improving their reading, listening, speaking, and writing skills. In order to achieve this, learners need to attain a sufficient level of vocabulary knowledge. This is because learners' vocabulary levels are seen as a criterion in terms of their proficiency in a foreign language and their language performance (Juanggo, 2018; Karadağ, 2018), and it is considered an important factor in the development of language skills, primarily of reading and listening (Cheng \& Matthews, 2018; CastroGarcia, 2017; Escobar, Kalashnikova \& Escudero, 2018). Moreover, the depth and width of vocabulary knowledge are also indicators of second language speaking skills (Enayat \& Derakhshan, 2021). In addition, it is known that vocabulary development activities improve learners' general language levels (Topkaraoğlu \& Dilman, 2013; Masrai \& Milton, 2018; McLean, Stewart, \& Batty, 2020; Matthews, 2018; Koizumi \& In'nami, 2013; Stæhr, 2008) and the comprehension levels of learners of Turkish as a foreign language are related to reading texts, but primarily reading words fluently (Ülper, 2018). Therefore, vocabulary teaching plays an important role in the success of foreign language teaching in relation to language skills. The content of the foreign language teaching program varies according to the foreign language learning purpose of the learners: as teaching for general communication purposes or for specific communication purposes. Academic language teaching is a sub-branch of language teaching for specific purposes 
that is shaped according to the needs of learners in academic contexts such as education or the work environment. The difference between foreign language teaching for academic purposes and foreign language teaching for general purpose is that the curriculum is designed by focusing on the special communication needs of the learners in a certain academic context, rather than teaching a language for general purpose (Kocaman-Gürata \& Durmuş, 2020). In this context, the term academic language typically refers to school or other academic communication environments where the content of knowledge is found, acquired, and applied (Heppt \& Stanat, 2020). Although dimensions of general-purpose language and academic language overlap, the differences in the content and form of academic language significantly affect the performance levels of students (Demirel, 2020). The sophisticated vocabulary of academic language is a feature that distinguishes it from the basic language (Zucker, Carlo, Montroy \& Landry, 2021). In addition, in terms of education, the qualifications of the educational materials in academic Turkish in terms of vocabulary are taken into account when designing a curriculum for the language that learners will use and encounter in academic environments in academic language teaching. Furthermore, it is important for learners to develop their academic vocabulary in academic Turkish lessons for the success of academic Turkish education.

\section{Literature review}

\section{Academic Vocabulary}

Words are units of conceptual or functional value spread throughout the language. Thus, the frequency of use of words may vary according to the texts in which they are used, depending on their conceptual value. It is accepted that some words are used more frequently in academic texts than in other fields (Hyland \& Tse, 2007) and words that are used more frequently in academic texts than in non-academic texts are classified as academic words (Malmström, Pecorari, \& Shaw, 2018). These words, which become prominent in terms of use in academic texts, are named after being differentiated into general-purpose academic words and special-purpose academic words or academic words and technical words. Accordingly, the vocabulary in academic texts is divided into two categories: special-purpose academic words, which express words that are frequently used in certain disciplines, such as the word 'mathematics', and general-purpose academic words, which are commonly used in all disciplines, such as the word 'examine'. Along with this distinction, in the literature, a distinction between academic words and technical words is also made. According to this, academic words are composed of academic texts, high school and university textbooks and journals, or vocabulary in academic texts other than general texts, while technical words represent words in special fields and specific disciplines such as law, mathematics, chemistry, and philosophy (Nation \& Newton, 1996; Yang, 2015). Academic vocabulary is often functionalized as designated academic lexemes that students are likely to use at university (Skoufaki \& Petrić, 2021). In general terms, academic vocabulary lists include words that are common in academic texts and do not have this commonality anywhere else such as 'accumulate', 'achieve', 'compound', 'complex', and 'proportion', while technical vocabulary refers to vocabulary that is useful for learners to use language for specific purposes, such as reading academic texts in certain 
disciplines or attending conferences on certain topics (Nation, 2001). While there are academic words in a certain percentage in academic texts, they differ in terms of type, frequency, collocation, and meaning in different disciplines (Hyland \& Tse, 2007). The fact that academic and technical words are found in academic texts in a certain ratio in terms of number (frequency and percentage) and usage (type, collocation, meaning) necessitates academic vocabulary teaching in order to understand academic texts. In the literature, it is stated that the vocabulary in the text should be known at the rate of $80-89 \%$ in order to understand listening texts and 95\% in short texts (Bonk, 2000), but in later research (Schmitt, 2008) there are findings that at least $90 \%$ should be known for an ideal level of understanding. A sufficient level of academic vocabulary knowledge is required to attain 95\%-98\% of the vocabulary in the texts (Pecorari, Shaw \& Malmström, 2019). In addition, improving academic vocabulary also contributes to students' academic writing (Vongpumivitch, Huang \& Chang, 2009; Khani \& Tazik, 2013). In the present research, word lists were extracted from the texts used in academic Turkish teaching and, with the help of these word lists, it was aimed to describe the position of academic words in Turkish in the texts used in teaching academic Turkish and to use them in teaching academic Turkish. Vocabulary lists are a method used in teaching vocabulary (Green, 2019; Lei \& Liu, 2016). This method is helpful for learners in terms of where to start, especially at the beginner level, and is of great convenience to educators when preparing materials and textbooks (Brezina \& Gablasova, 2013). The present research is important in terms of determining the numerical values of academic words in Turkish in academic texts based on the vocabulary in academic Turkish language sets, their conceptual description by separating them from terms and general usage words, and their application for teaching vocabulary and concepts in academic Turkish classes.

\section{Methodology}

The research sample consists of the vocabulary in academic Turkish, social sciences, and engineering/health sciences textbooks. In this context, a total of 2000 different lexemes were obtained from the textbooks "Academic Turkish in Social Sciences for International Students (Volumes I-II)", published by Kültür-Sanat Bookstore for the field of social sciences, and the textbook "Academic Turkish Social Sciences for International Students", prepared by Can Ofset. A total of 1943 different lexemes were obtained from the textbook "Academic Turkish in Science and Health Sciences for International Students (Volume III)", published by the Culture-Art printing house, and "Academic Turkish Sciences for International Students" and "Academic Turkish Health Sciences for International Students", published by Can Ofset, in the field of engineering sciences and health sciences. Non-probability sampling was used in the research. In this type of sampling, the probability of the units entering the sample is not the same or the probability is unknown, so the results cannot be generalized to the population (Erkuş, 2017). In the research, inferences were made on the data and no generalization was made to any population. The research was descriptive, investigating the vocabulary in academic Turkish language sets in terms of academic words. The research was in relational research format. Relational research studies are those in which cause-effect relationships cannot be 
established, and where change or control, even partial, is not possible due to its nature or practical reasons (Erkuş, 2017). In the research, the vocabulary between social sciences and engineering/health sciences within the scope of academic Turkish language sets was statistically compared.

\section{Data collection and analysis}

The lexemes that make up the research data were obtained from the textbooks used in academic Turkish courses for students who will study at universities in Turkey: "Academic Turkish in Social Sciences for International Students I-II" and "Academic Turkish in Sciences and Health Sciences for International Students III," which are created by Istanbul University, and the textbooks "Academic Turkish Sciences for International Students," "Academic Turkish Social Sciences for International Students," and "Academic Turkish Health Sciences for International Students," prepared by Erciyes University.

The word list in the academic texts that constitute the research data is divided into 3 categories: general usage words, academic words, and technical words. Like Coxhead (2000), but based on the Turkish language, the first 2000 most frequently used words are accepted as general usage words. To determine this, the lexemes in each category were compared with the 2000 most frequently used lexemes in Turkish according to the Frequency Dictionary of Turkish (FDT) (Aksan, Aksan, Mersinli \& Demirhan, 2017), and the words the same as these lexemes were marked as general usage words and excluded from the scope.

Academic words refer to words that are commonly used in different academic texts, while technical words refer to words that are commonly used in certain fields (Nation, 2001). In order to specify technical words, the word list forming the research data was compared with the Turkish Language Association Science and Art Terms Dictionary (TLA-SATD). TLA-SATD is an electronic dictionary that includes a total of 93 dictionaries of terms in various social, natural, engineering, and health sciences disciplines. Based on TLA-SATD, the words used as terms were marked as technical words and excluded from the scope. Vocabulary units other than general usage words and technical words were accepted as academic words and included in the research.

In order to collect these data, the textbooks were first converted into PDF files, and then the word lists in the textbooks in the research and the frequency of use of these words were obtained by using the programs ABBYY Fine Reader 9.0 and kfNgram. Within the scope of the research, first, the word list and frequency of the words in the social sciences and engineering/health sciences textbooks were specified, and the numbers of general usage, academic, and technical words in these fields were determined. By comparing the obtained vocabulary with the FDT and TLA-SATD, general usage and technical words in related fields were extracted. Accordingly, 1176 of the 2000 lexemes in the field of social sciences were marked as general usage words and 465 of them were marked as technical words; thus, 359 academic words were obtained, except for general usage words and technical words in the field of social sciences. In the field of engineering/health sciences, 
1012 of 1943 lexemes were marked as general usage words and 643 as technical words, and the remaining 291 lexemes were accepted as academic words and included in the scope of the research. Then the obtained words and their frequencies were analyzed in terms of their conceptual properties and frequency values. Lexemes classified as social sciences and engineering/health sciences words were evaluated in terms of their percentages in their categories, the most frequently used word types, and conceptual features, and the differences in usage between social sciences and engineering/health sciences were analyzed with the Mann-Whitney U test.

\section{Results}

The numerical values of the lexemes in social sciences and engineering/health sciences textbooks used in academic Turkish lessons are shown below.

\section{Academic Vocabulary in Social Sciences}

In the research, a total of 2000 different lexemes were listed from the words and verbs that have conceptual value from the "Academic Turkish in Social Sciences for International Students I-II" and "Academic Turkish Social Sciences for International Students" textbooks.

Figure 1. Academic Vocabulary in Social Sciences

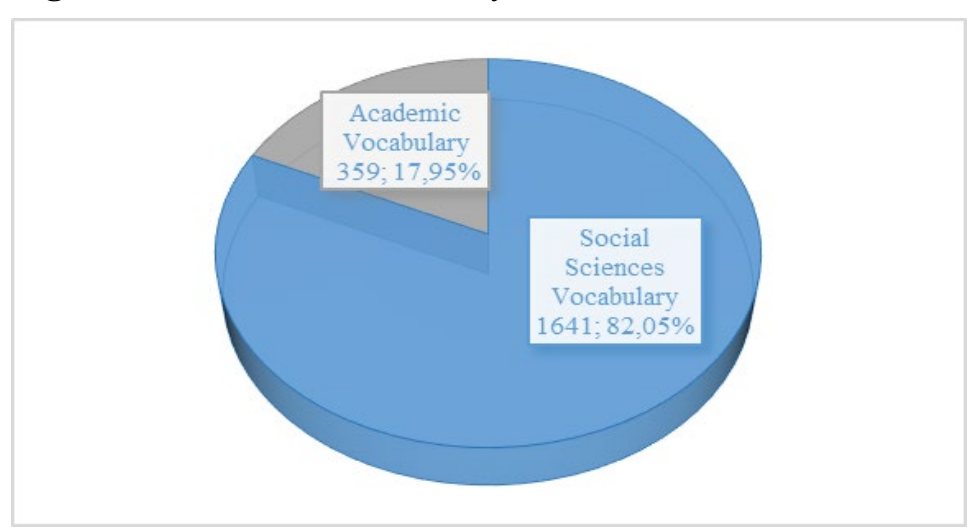

According to Figure 1, there are 2000 words in total in the field of social sciences and 359 of these words are academic words, while the number of general usage and technical words is 1641 . Academic words constitute $17.95 \%$ of the words in the field of social sciences numerically. Tables 1 and 2 show the 20 most frequently used words in academic Turkish social sciences textbooks that make up the social sciences corpus in the research.

Table 1. Social sciences corpus 10 most frequently used words list

\begin{tabular}{lclc}
\hline Words & Frequency & Words & Frequency \\
\hline 1. ol- (to be/to have) & 1516 & 6. et- (to make) & 480 \\
\hline 2. insan (human) & 545 & 7. sosyal (social) & 452 \\
\hline 3. dil (language) & 507 & 8. bilgi (information) & 445 \\
\hline 4. bilim (science) & 490 & 9. yer (place) & 444 \\
\hline 5. metin (text) & 481 & 10. aşağ1 (down) & 386 \\
\hline
\end{tabular}

As shown in Table 1, the verb ol- (to be/to have) is the most frequently used auxiliary verb in the field of social sciences and clearly differs in frequency from the 
words that follow it. In the field of social sciences, the word ol- (to be/to have) is used either as a verb, as in "... problem olabilir (may be a problem), ... etkisi olabilir (may have an effect)", or as an auxiliary verb, as in "ait olduğu... (to belong), sahip olduğu... (to have)". The frequencies of the other words "et- (to make)" and "yap- (to do)", which are used as auxiliary verbs in Turkish, are lower than those of the verb ol- (to be/to have). It is seen that the verb et- (to make), with a frequency of 480, is used in auxiliary verb position, as in "dahil et- (to include) and ifade et- (to express)", and in idioms such as "göz ardı et(to ignore)".

Table 2. Social sciences corpus 11-20 most frequently used words list

\begin{tabular}{lclc}
\hline Words & Frequency & Words & Frequency \\
\hline 11. tartış- (to discuss) & 51 & 16. ayrıl- (to leave) & 45 \\
\hline 12. tartışma (discussion) & 51 & $\begin{array}{c}\text { 17. kavrayabilme (ability to } \\
\text { comprehend) }\end{array}$ & 45 \\
\hline 13. birakı1- (to be left) & 50 & 18. literatür (literature) & 45 \\
\hline 14. maliye (finance) & 50 & 19. dayan- (to hang on) & 39 \\
\hline 15. yazıl- (to be written) & 50 & 20. satın al- (to buy) & 39 \\
\hline
\end{tabular}

The verb yap- (to make), with a frequency of 255 , is used as “...edebi yapan... (one engaged in literary)". The words "insan (human), dil (language), and önemli (important)", which are among the 20 most frequently used words in the field of social sciences, are among the words that learners can encounter outside of academic Turkish lessons; they are also used in everyday language. However, the words "metin (text), bilgi (information), kaynak (source), and etkinlik (activity)" are of important conceptual value in academic environments. It is noteworthy that these words are used with high frequency in academic texts in social sciences. The 20 most frequently used words in the Social Sciences corpus academic word list are shown in Tables 3 and 4.

Table 3. Social sciences corpus 10 most frequently used academic words list

\begin{tabular}{lclc}
\hline Words & Frequency & Words & Frequency \\
\hline 1. yapil- (to be done) & 176 & 6. alın- (to be taken) & 67 \\
\hline 2. bulun- (to be found) & 131 & 7. getiril- (to be brought) & 60 \\
\hline 3. tarihî (historical) & 100 & 8. başla- (to start) & 58 \\
\hline 4. edil- (to be made) & 76 & 9. ipucu (clue) & 56 \\
\hline 5. işaretle- (to mark) & 71 & 10. görül- (to be seen) & 55 \\
\hline
\end{tabular}

In the list of the 20 academic words most frequently used in social sciences, passive verbs stand out. Four of the five most frequently used words are verbs (yapil- (to be done), bulun- (to be found), edil- (to be made), and işaretle- (to mark)) and three of these verbs (yapil- (to be done), bulun- (to be found), and edil- (to be made)) are passive. When examined in terms of frequency, the frequency of use of academic words changes gradually after the first three words. The fact that the words "metin (text), bilgi (information), kaynak (source), and etkinlik (activity)" in Table 1 in the academic word list were not included in the academic word list due to the meaning they have as terms caused an increase in the number of verbs in the 20 most frequently used academic word list. When the 359 academic words in the field of social sciences are examined in general, the most frequently used word is "yapıl- (to be done)", with 176 uses. This word, which is the passive form of the word "yap- (to make)", has been included in the list as a separate word since it is used as a headword in the GTS. While the word "yap- (to make)" is in first place 
in the general list, the fact that the passive word "yap1l- (to be done)" is in the academic word list after the general usage and technical words are removed shows that this word and its derivatives appear in academic texts with a high frequency. Academic words in the field of social sciences include words that are used in academic texts such as "tarihi (historical)" and "ipucu (clue)" that do not have a specific use in a particular field.

Table 4. Social sciences corpus 11-20 most frequently used academic words list

\begin{tabular}{lclc}
\hline Words & Frequency & Words & Frequency \\
\hline 11. tartış- (to discuss) & 51 & 16. ayrıl- (to leave) & 45 \\
\hline 12. tartışma (discussion) & 51 & $\begin{array}{l}\text { 17. kavrayabilme (ability to } \\
\text { comprehend) }\end{array}$ & 45 \\
\hline 13. birak1l- (to be left) & 50 & 18. literatür (literature) & 45 \\
\hline 14. maliye (finance) & 50 & 19. dayan- (to hang on) & 39 \\
\hline 15. yazıl- (to be written) & 50 & 20. satın al- (to buy) & 39 \\
\hline
\end{tabular}

Academic words in the field of social sciences include words that have a more general meaning compared to the terms used in academic texts such as "kat1lımc1 (participant)", "dinsel (religious)", and "kazanım (learning outcome)". When the verb usages in the academic word list in the field of social sciences are examined, it is seen that "bulun- (to be found)", with 131 repetitions, is the most frequently used verb except for the verb "yapıl- (to be done)". Moreover, the verb "edil- (to be made)" occurs with 76 repetitions in compound words such as "elde edil- (to be obtained), kabul edil- (to be accepted), tercih edil- (to be preferred), and ifade edil- (to be expressed)". It is noteworthy that these words, which are most frequently used in academic verb usage in the field of social sciences, have a passive structure. Apart from these, there are active verbs such as "başla- (start), tartış- (discuss), dayan- (to hang on), and satın al- (to buy)" in the field of social sciences.

Within the scope of the research, the total vocabulary frequency in the field of social sciences and the frequency of use of academic words were specified and the result is shown in Figure 2.

Figure 2. Frequency of Use of Academic Words in the Field of Social Sciences

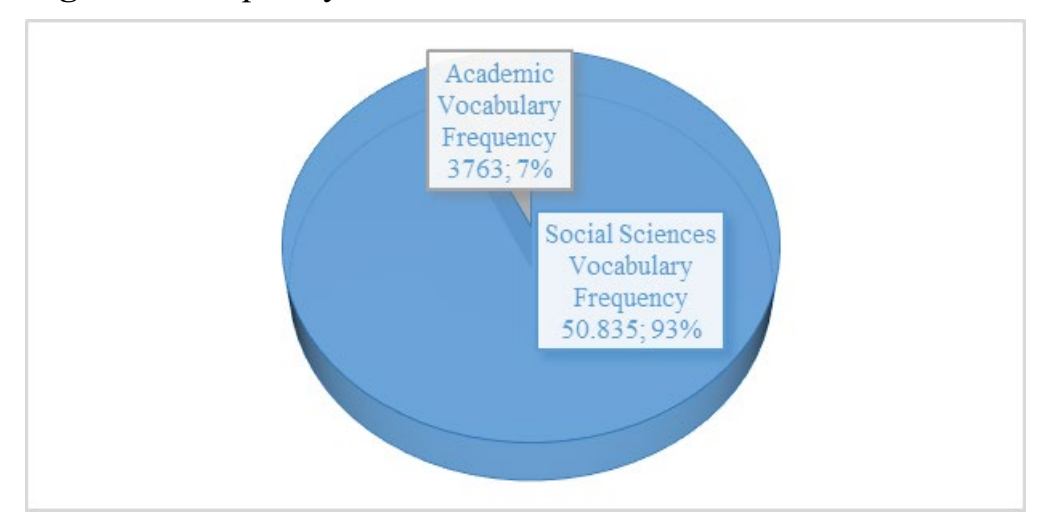

According to the figure above, the total frequency of use of 359 vocabulary units in the field of social sciences is 3763 and the frequency of use of general and technical words is 50,835 . When the data are calculated in percentiles, the percentage of academic words in the field of social sciences is $7 \%$ in terms of frequency of use. From these findings, it is understood that the numerical percentage of academic words in the field of social sciences $(17.95 \%)$ is significantly higher than the percentage of usage (7\%). In this case, it can be 
concluded that the frequency of use of academic words in the field of social sciences is lower compared to the number of words.

\section{Academic Vocabulary in Engineering/Health Sciences}

In the present research, a total of 1943 different lexemes that have conceptual value were listed from the words and verbs in the "Academic Turkish in Engineering Sciences for International Students", "Academic Turkish in Health Sciences for International Students", and "Academic Turkish in Sciences and Health Sciences III" textbooks. Figure 3 shows the number and percentage of academic words in the field of engineering and health sciences.

Figure 3. Number and percentage of academic words in engineering/health science textbooks

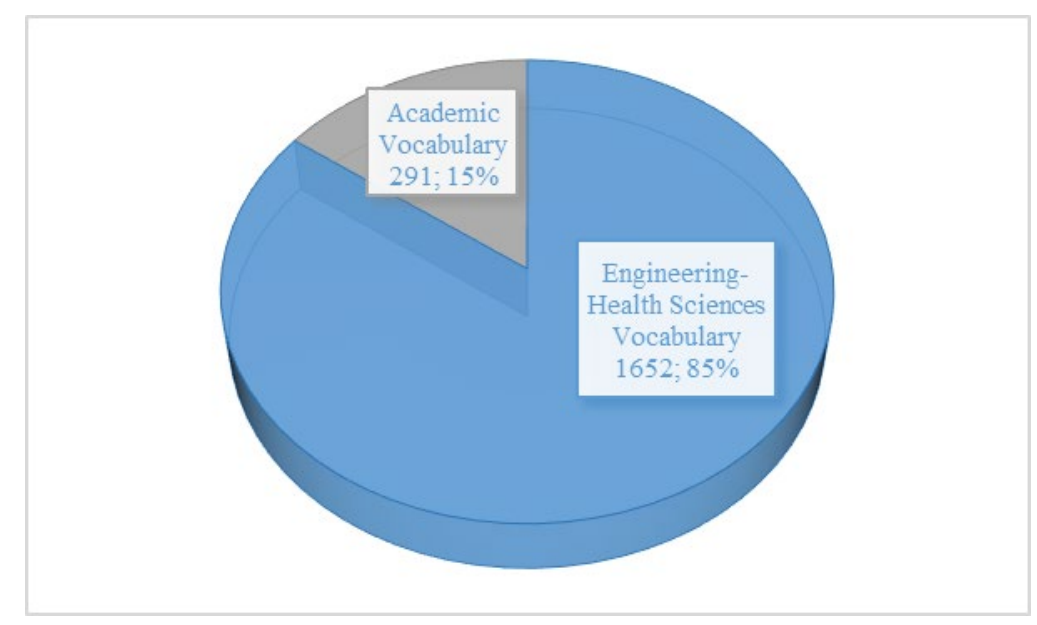

According to Figure 3, 291 out of 1943 vocabulary units in the field of engineering/health sciences were listed as academic words and these academic words constitute $15 \%$ of the vocabulary in the field of engineering/health sciences. The total number of technical and general usage words in the field of engineering/health sciences is 1652. Technical and general usage words constitute $85 \%$ of the total vocabulary in engineering/health sciences.

Table 5. List of the 10 most frequently used words in the corpus of engineering/health sciences

\begin{tabular}{lclc}
\hline Words & Frequency & Words & Frequency \\
\hline 1. ol- (to be/to have) & 1241 & 6. etkinlik (activity) & 584 \\
\hline 2. bilim (science) & 792 & 7. et- (to make) & 444 \\
\hline 3. metin (text) & 721 & 8. aşă̆ (down) & 431 \\
\hline 4. böcek (bug) & 710 & 9. sağlik (health) & 411 \\
\hline 5. akademik (academic) & 628 & 10. iç (inside) & 407 \\
\hline
\end{tabular}

The most frequently used word in the vocabulary of the corpus of engineering/health sciences is the verb "ol- (to be/to have)" with 1241 repetitions and a clear difference. In the relevant textbooks, the verb in question is used as a verb, as in "... bilim olarak... (as a science) and ...metodolojik olarak...(methodologically)", and as an auxiliary verb, as in "...yardımc1 olur (helps)". The auxiliary verb "et- (to make)", which is in seventh place with 444 repetitions, is used in verbs such as "elde et- (to obtain) and takip et- (to follow)" in the relevant textbooks. Apart from this, it is seen that three of the first five words (bilim (science), metin (text), akademik (academic)) in the list of most frequently used academic 
words in engineering/health sciences are words that have conceptual value in academic discourse.

Table 6. List of the 11-20 most frequently used words in the corpus of engineering/health sciences

\begin{tabular}{lclc}
\hline Words & Frequency & Words & Frequency \\
\hline 11. bilgi (information) & 391 & 16. bölüm (section) & 284 \\
\hline 12. Türkçe (Turkish) & 374 & 17. konu (topic) & 274 \\
\hline 13. alan (field) & 362 & 18. çalışma (study) & 270 \\
\hline 14. ilgili (related) & 316 & 19. hastalık (illness) & 255 \\
\hline 15. kullanıl- (to be used) & 286 & 20. kaynak (source) & 252
\end{tabular}

Words such as "etkinlik (activity), alan (field), kaynak (source)", which are among the top 20 most frequently used words in engineering/health sciences textbooks, can also be evaluated in this way. When the verb usages are examined, it is seen that there is the passive verb "kullanıl- (to be used)", except for words that can be used as auxiliary verbs such as "ol- (to be/to have) and et- (to make)". In this respect, it can be said that there are mostly nouns with conceptual value in the list of engineering/health sciences.

Table 7. List of the 10 most frequently used academic words in the corpus of engineering/health sciences

\begin{tabular}{lclc}
\hline Words & Frequency & Words & Frequency \\
\hline 1. kullanıl- (to be used) & 286 & 6. yapıl- (to be done) & 150 \\
\hline 2. çalışma (study) & 270 & 7. elde et- (to be obtained) & 90 \\
\hline 3. bulun- (to be found) & 237 & 8. sosyal (social) & 84 \\
\hline 4. fen (natural sciences) & 217 & 9. işaretle- (to mark) & 80 \\
\hline 5. veril- (to be given) & 180 & 10. literatür (literature) & 77 \\
\hline
\end{tabular}

The most frequently used lexeme in the research is the verb "kullanil- (to be used-)", with 286 repetitions. This word is followed "çalışma (study)", with 270 repetitions, and "bulun- (to be found)", with 237 repetitions. It is noteworthy that verbs such as "veril- (to be given, edil- (to be made), yapıl- (to be done), elde et- (to obtain), and işaretle- (to mark)" are in the majority in the ten most frequently used lexical units in the academic vocabulary list in the field of engineering/health sciences. This can be conceptually attributed to the fact that more terms are used in the field of engineering/health sciences than in the social sciences.

Table 8. List of the 11-20 most frequently used academic words in the corpus of engineering/health sciences

\begin{tabular}{lclc}
\hline Words & Frequency & Words & Frequency \\
\hline mühendislik (engineering) & 70 & getirebilme (to be able to bring) & 46 \\
\hline görül- (to be seen) & 59 & isten- (to be wanted) & 44 \\
\hline robotik (robotics) & 58 & belirt- (to indicate) & 44 \\
\hline ayırt (distinguish) & 57 & edebilme (to be able to make) & 43 \\
\hline robot (robot) & 56 & $\begin{array}{l}\text { kavrayabilme (ability to } \\
\text { comprehend) }\end{array}$ & 42 \\
\hline
\end{tabular}

When academic words other than general usage and technical words are examined in engineering/health sciences textbooks, it is seen that three of the first five most frequently used words (kullanil- (to be used), bulun- (to be found), and veril- (to be give)) are verbs and these verbs are in passive form. Then come the verbs "yapıl- (to be done), elde et- (to obtain), işaretle- (to mark), görül- (to be seen), isten- (to be wanted), and belirt- (to indicate)" in the list. 
Academic words in engineering/health sciences are similar to those in the field of social sciences in terms of passive verb usage. In this respect, it appears that there is a certain standard in the academic Turkish language structure. In the list, it is seen that the words that are frequently used in academic environments such as "çalışma (study), ayırt (distinguish), kavrayabilme (ability to comprehend), fen (natural sciences), and sosyal (social)" and academic words that fall into the field of engineering such as "robotik (robotics) and robot (robot)" are used.

In the list of academic words in the field of natural sciences and health sciences, there are words that are in more general use in academic texts such as "anlayabilme (ability to understand), kavrayabilme (ability to comprehend), and uygun (appropriate)" along with the words "mühendislik (engineering), robotik (robotics), astrolog (astrologist)". In the use of verbs, it is understood that active and passive verbs such as "tartış- (to discuss), dikkate al- (to take into account), bırakıl- (to be left), and sağlan- (to provide)" and mostly verbs expressing actions in academic discourse are dominant. Within the scope of the research, it was seen that 1943 lexemes are used 49,516 times in the field of engineering and health sciences. The numerical information on the use of academic words and technical and general usage words in the engineering/health sciences corpus is shown in Figure 4.

Figure 4. Frequency and frequency percentage of academic words in engineering/health sciences textbooks

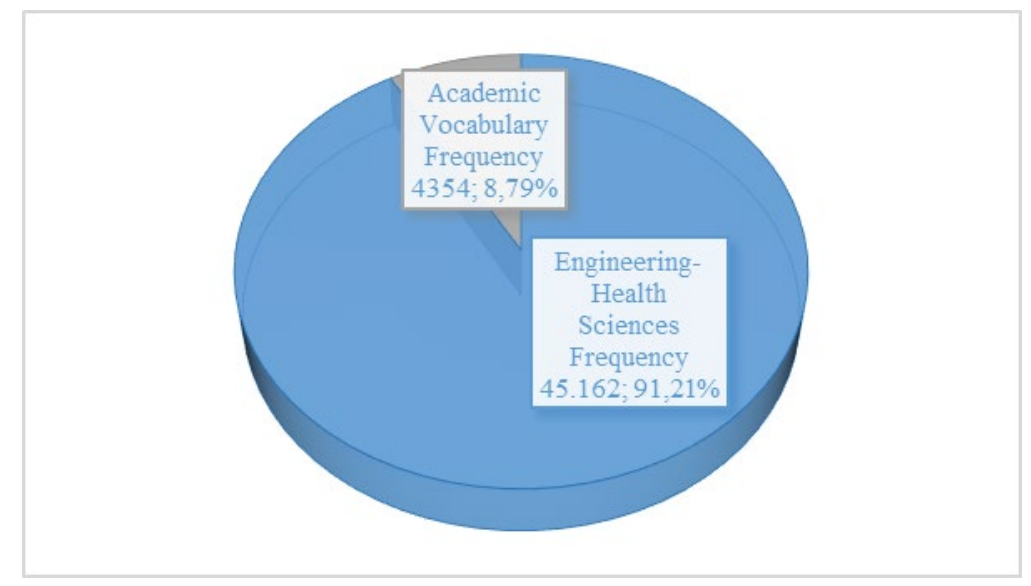

According to the chart above, the total frequency of academic words in the field of engineering/health sciences is 4354 . The frequency of academic words constitutes $8.79 \%$ of the engineering/health sciences corpus. The total usage frequency of technical and general usage words in the field of engineering/health sciences is 45.162 and the percentage is $91.21 \%$. While academic words in the field of engineering/health sciences constitute $15 \%$ of the total vocabulary in this field, they constitute $8.29 \%$ in terms of use. In this case, academic words in the field of engineering/health sciences also decrease significantly in terms of use.

\section{Academic Vocabulary Frequency Differences}


Within the scope of the research, the total word difference between social sciences and engineering/health sciences was analyzed with the Mann-Whitney $U$ test. The result is shown in Table 9.

Table 9. Mann-Whitney $U$ table showing the difference between the frequencies of the lexemes in the fields of social sciences and engineering/health sciences

Social Sciences and Engineering

/Health Sciences Total Number of

Lexemes

\begin{tabular}{llllll} 
& & Minimum & Z & $\mathrm{p}$ \\
$\mathrm{N}$ & Mean & & Maximum & & \\
\hline 2000 & 27.29 & 1 & 1516 & -1.131 & .258 \\
1943 & 25.48 & 1 & 1241 & & \\
\hline
\end{tabular}

\begin{tabular}{lllll}
\hline Social Sciences & 2000 & 27.29 & 1 & 1516 \\
\hline Engineering and Health Sciences & 1943 & 25.48 & 1 & 1241
\end{tabular}

According to Table 5, the average frequency of 2000 lexemes in the field of social sciences is 27.29 and the average frequency of 1943 lexemes in the field of engineering/health sciences is 25.48. While the lexemes in both fields are used at least once, the most frequently used lexeme in the field of social sciences is used 1516 times, and in the field of engineering/health sciences it is used 1241 times. There is no statistically significant difference between the frequencies of the total lexemes in the field of social sciences and the lexemes in the field of engineering/health sciences ( $\mathrm{p} .258>\mathrm{p} .05)$. From these findings, it is understood that the vocabulary in social sciences textbooks and engineering/health sciences textbooks shows a balanced distribution in terms of their frequencies.

Table 10. Mann-Whitney $U$ table showing the difference between the frequencies of academic vocabulary in the fields of social sciences and engineering/health sciences

Academic Vocabulary in the Fields of Social Sciences and Engineering /Health Sciences

\begin{tabular}{lllllll} 
& $\mathrm{N}$ & Mean & Minimum & Maximum & Z & $\mathrm{p}$ \\
\hline Social Sciences & 359 & 10.42 & 1 & 176 & & \\
\cline { 1 - 4 } Engineering/Health Sciences & 291 & 14.96 & 2 & 286 & -1.410 & .158 \\
\hline
\end{tabular}

According to Table 9, while the average of 359 academic words in the field of social sciences is 10.42 , the minimum number of uses is 1 , and the maximum number of uses is 176. The number of academic words in the field of engineering/health sciences is 291 , the minimum number of uses is 2 , and the maximum number of uses is 286 . The average number of uses of academic words in the field of engineering/health sciences is 14.96. There is no statistically significant difference between the frequency of use of academic words in social sciences and engineering/health sciences (p.158>p.05). Thus, academic words have a balanced distribution within their fields.

\section{Discussion}

In academic vocabulary studies, first of all, it is necessary to decide which words are academic words. Studies on academic vocabulary have increased in recent years, but it is not easy to create a definite definition of the concept of academic vocabulary. In academic vocabulary studies, academic words are distinguished from words with a high frequency of use in everyday language (Coxhead, 2000; Gardner \& Davies, 2015). In this respect, academic words are separated from general usage words in the research. Academic words are also separated from technical words that have the meaning of terms and express the 
vocabulary that is used in academic texts but differs from the high frequency words covering the texts in general and terms specific to various disciplines. It is seen that these academic words lexically constitute $17.95 \%$ of the texts in social sciences and $15 \%$ in engineering/health sciences. It is understood that it constitutes a significant percentage of the texts in terms of the number of single uses. However, in terms of frequency, it decreases to $7 \%$ in social sciences and $8.79 \%$ in engineering/health sciences. This shows that the frequency of use of words is low, but it is at a significant percentage in terms of single use. This finding is compatible with the finding reported by Coxhead (2000, p. 214) concerning English language: "Academic words (e.g., substitute, underlie, establish, inherent) are not highly salient in academic texts, as they are supportive of but not central to the topics of the texts in which they occur". Considering the findings of other studies (Bonk, 2000; Schmitt, 2008; Pecorari, Shaw \& Malmström, 2019) investigating the relationship between vocabulary knowledge and comprehension, it is possible to say that percentages such as $15 \%$ and approximately $18 \%$ in terms of single uses are quite decisive. Within the scope of the present research, it was determined that both the total vocabulary frequencies (p.258>p.05) and academic word frequencies (p.158>p.05) in social sciences and engineering/health sciences do not have a statistically significant difference. The absence of a significant difference between the total vocabulary frequencies indicates that the vocabulary in academic texts does not change in terms of disciplines. In addition, academic vocabulary does not differ in terms of frequency on the basis of disciplines either. This enables a generalization of $7 \%-8 \%$ in terms of the frequency percentages of academic words in the texts. This number is also in line with the implications of other studies on English language (Nation, 2001; Hyland \& Tse, 2007). From a conceptual point of view, it can be concluded that academic words, with words such as sözlü (verbal), kazanım (outcome), faydalı (useful), belirgin (distinctive), and esaslı (essential), have the characteristics of giving academic quality to written and oral discourse, increasing the impact of the discourse, and, in this respect, it affects the pragmatic aspect of academic discourse. However, there are also words open to discussion regarding the clear distinctions between their category as academic words and terms, such as Hristiyanlik (Christianity), tüzel (corporate), and epigrafi (epigraphy). Since these words are not included as terms in the TDK Science and Art Terms Dictionary, they are listed as academic words. However, they are words worth discussing in terms of conceptual value.

In the present research, finally, a list of words obtained from the textbooks that make up the research corpus and suggested to be used in concept teaching in academic Turkish lessons is presented. Word lists are a technique used especially in purposeful vocabulary teaching. Most word lists are used to determine the purpose of vocabulary teaching, evaluate vocabulary knowledge and its improvement, analyze text difficulty and richness, create and adapt reading materials, design vocabulary teaching tools, decide on the vocabulary of academic curriculum items, and meet other important academic needs (Gardner \& Davies, 2014). In addition, by examining the academic word list produced, it is possible to evaluate the academic words presented to the learners in academic Turkish lessons with different studies.

\section{Conclusion}


As a result of the research, academic words with a numerically distinctive feature have been listed, unlike the high frequency words and terms used in everyday language used in academic texts. It is difficult to determine precise boundaries in terms of semantics when distinguishing between academic words and technical words (terms). However, apart from the term feature, it is also a fact that there are words whose frequency of use becomes evident in academic texts compared to the vocabulary in everyday language, and, accordingly, there are words that are used prominently both in academic environments and in the discourses of people with a high level of education. It is seen that these words, which are accepted as academic words, have a lower frequency of use (7\%-8\%) than the number of lexical uses (15\%-18\%), but are in a decisive position in terms of improving academic comprehension and expression skills when the number of single uses is taken into account. According to the results of the present research, it is seen that these Turkish words, which do not differ according to the academic types of the texts, are close to English language in terms of frequency of use and the number of occurrences in the texts. In addition, it is understood that academic words generally differ from terms and general usage words in terms of conceptual and usage frequency, and they are in a decisive position regarding academic comprehension skills considering their usage percentages in Turkish academic language.

\section{References}

Aksan, Y., Aksan, M., Mersinli, Ü. \& Demirhan, U. U. (2017). A Frequency dictionary of Turkish core vocabulary for learners. Routledge Pub.

Alipoor, R. \& Jadidi, E., (2016). The Relationship between Iranian EFL Teachers' Reflection and their Cognition about Vocabulary Teaching Style. Procedia - Social and Behavioral Sciences, 232, 769 - 775, doi: 10.1016/j.sbspro.2016.10.104

Beach, K. D., Sanchez, V., Flynn, J. L. \& O’Connor E. (2015). Teaching academic vocabulary to adolescents with learning disabilities. Teaching Exceptional Children, Vol. 48, No. 1, pp: 36-44.

Bonk, W. (2000). Second Language Lexical Knowledge and Listening Comprehension. International Journal of Listening, 14(1), 14-31. Doi: 10.1080/10904018.2000.10499033

Brezina, V. \& Gablasova, D. (2013). Is There a Core General Vocabulary? Introducing the New General Service List. Applied Linguistics 36(1), 1-23. Doi: 10.1093/applin/amt018

Castro-García, D. (2017). Receptive vocabulary measures for EFL Costa Rican high school students. International Journal of English Studies, 17(2), 81-99. $10.6018 / \mathrm{ijes} / 2017 / 2 / 265681$

Cheng, J. \& Matthews, J. (2018). The relationship between three measures of L2 vocabulary knowledge and L2 listening and reading. Language Testing, 35(1), 3-25. https://oi.org/10.1177/0265532216676851.

Coxhead, A. (2000). A New Academic Word List. TESOL Quarterly, 34(2), 213-238. Doi: $10.2307 / 3587951$

Demir, N. (2017). Temel Kavramlar [Basic Concepts]. In H. Pilancı (Eds.), Türkçe Biçim Bilgisi, (pp. 2-25). Anadolu Üniversitesi yayıncılık.

Demir, N. \& Y1lmaz, E. (2012). Türk dili el kitabı [Turkic Language Handbook]. Grafiker Yayıncilik. 
Demirel, G. (2020). Akademik Türkçe derslerinin kapsamı ve uygulama örnekleri [A scope of academic Turkish lessons and examples]. In B. Tüfekçioğlu (Eds.), Akademik amaçlar için Türkçe ögretimi (pp. 89-100). Ankara: Pegem Akademi.

Enayat, M. J. \& Derakhshan, A., (2021). Vocabulary size and depth as predictors of second language speaking ability. System 99(1), pp: 1-11. Doi: 10.1016/j.system.2021.102521

Erkuş, A. (2017). Davranış bilimleri için bilimsel araştırma süreci. [Scientific research process for behavior sciences]. Seçkin Yayıncılık

Escobar, G. P., Kalashnikova, M. \& Escudero P. (2018). Vocabulary matters! the relationship between verbal fluency and measures of inhibitory control in monolingual and bilingual children. Journal of Experimental Child Psychology 170, 177-189. 10.1016/j.jecp.2018.01.012

Gardner, D. \& Davies, M., (2014). A New Academic Vocabulary List, Applied Linguistics 35/3: 305-327.

Green, C. (2019). Enriching the academic wordlist and secondary vocabulary lists with lexicogrammar: Toward a pattern grammar of academic vocabulary. System 87(1), 1-10. Doi: 10.1016/j.system.2019.102158

Heppt, B. \& Stanat, P., (2020). Development of academic language comprehension of German monolinguals and dual language learners. Contemporary Educational Psychology, 62, July, pp: 1-15. Doi: 10.1016/j.cedpsych.2020.101868

Hyland, K. \& Tse, P. (2007). Is There an "Academic Vocabulary"?, TESOL Quarterly, 41(2) pp. 235-253.

İmer, K., Kocaman, A. \& Özsoy, A. S. (2011). Dilbilim Sözlüğü [Linguistics dictionary]. İstanbul: Boğaziçi Ünv. Yay.

Jackson, H. (2016). Sözlükbilime giriş [Introduction to lexicography]. (Trans. Gürlek, M. \& Patat, E.) Kesit Yay.

Juanggo, W. (2018). Investigating lexical diversity and lexical sophistication of productive vocabulary in the written discourse of Indonesian EFL learners. Indonesian Journal of Applied Linguistics, 8(1), 38-48. Doi: 10.17509/ijal.v8i1.11462.

Karadağ, Ö. (2018). Dil eğitimi araştırmaları için bir değişken önerisi: Kelime hazinesi katsayısı [A Variable Suggestion for Language Education Research: Vocabulary Coefficient]. Ana Dili Eğitimi Dergisi, 6(2), 532-537. Doi: 10.16916/aded.372078.

Khani, R. \& Tazik, K. (2013). Towards the Development of an Academic Word List for Applied Linguistics Research Articles. RELC Journal, 44(2) 209-232. Doi: $10.1177 / 0033688213488432$

Kocaman Gürata, E., \& Durmuş. M. (2020). Özel amaçlı yabancı/ikinci dil öğretimi kapsamında akademik amaçlı Türkçenin yeri [The position of Turkish for academic purposes within the scope of foreign/second language teaching for specific purposes]. In B. Tüfekçioğlu (Ed.), Akademik amaçlar için Türkçe öğretimi, (pp. 41-66). Pegem Akademi.

Koizumi, R. \& In'nami, Y. (2013). Vocabulary knowledge and speaking proficiency among second language learners from novice to intermediate levels. Journal of Language Teaching and Research, 4(5), 900-913. Doi: 10.4304/j1tr.4.5.900-913.

Lei, L. \& Liu, D. (2016). A new medical academic word list: A corpus-based study with enhanced methodology. Journal of English for Academic Purposes, 22. 42-53. Doi: 10.1016/j.jeap.2016.01.008

Malmström, H., Pecorari, D. \& Shaw, P., (2018). Words for what? Contrasting university students'receptiveand productive academic vocabulary needs. English for Specific Purposes, 50(1), 28-39. Doi: 10.1016/j.esp.2017.11.002. 
Masrai, A. \& Milton, J. (2018). Measuring the contribution of academic and general vocabulary knowledge to learners' academic achievement. Journal of English for Academic Purposes, 31(1), 44-57. Doi: 10.1016/j.jeap.2017.12.006

Matthews, J. (2018). Vocabulary for listening: Emerging evidence for high and mid-frequency vocabulary knowledge. System, 72(1), 23-36. Doi: 10.1016/j.system.2017.10.005.

McLean, S., Stewart, J. \& Batty, A. O. (2020). Predicting L2 reading proficiency with modalities of vocabulary knowledge: A bootstrapping approach. Language Testing, 37(3), 389-411. Doi: $10.1177 / 0265532219898380$.

Nation, I. S. P. (2001). Learning vocabulary in another language. Cambridge University Press.

Nation, P. \& Newton, J. (1996). Teaching vocabulary. In J. Coady \& T. Huckin (Eds.), Second Language Vocabulary Acquisition, (pp. 238-254). Cambridge University Press.

Pecorari, D., Shaw, P. \& Malmström, H. (2019). Developing a new academic vocabulary test. Journal of English for Academic Purposes, 39. 59-71. Doi: 10.1016/j.jeap.2019.02.004

Schmitt, N. (2008). Instructed Second Language Vocabulary Learning. Language Teaching Research, 12(3), 329-363. Doi: 10.1177/1362168808089921

Skoufaki, S. \& Petrić, B. (2021). Academic vocabulary in an EAP course: Opportunities for incidental learning from printed teaching materials developed in-house. English for Specific Purposes, 63, 71-85. Doi: 10.1016/j.esp.2021.03.002

Stæhr, L. S. (2008). Vocabulary size and the skills of listening, reading and writing. Language Learning Journal, 36(1). 139-152, 10.1080/09571730802389975

Topkaraoğlu, M. \& Dilman, H. (2013). Sözcük geliştirme aktivitelerinin öğrencilerin sahip oldukları genel dil seviyeleri üzerindeki etkisi [Effects of studying vocabulary enhancement activities on students' general language proficiency levels]. Batı Anadolu Ĕ̈itim Bilimleri Dergisi (BAED), 4(8), 15-29.

Turkish Language Association, (2021, May). Current Turkish Dictionary. https://sozluk.gov.tr/

Turkish Language Association, (2021, May). Turkish Language Association Science and Art Terms Dictionary. https://sozluk.gov.tr/

Ülper, H. (2018). Yabanc1 dil olarak Türkçe öğrenen öğrencilerin akıcı sözcük ve metin okuma becerileriyle kavrama becerileri arasındaki ilişkinin karşılaştırılması [Comparison of the Relationship between Word Reading Fluency and Text Reading Fluency of Students Learning Turkish as a Foreign Language]. Dil Eğitimi ve Araşstırmaları Dergisi, 4(1), 1-11.

Vongpumivitch, V., Huang, J-Y \& Chang, Y-C. (2009). Frequency analysis of the words in the Academic Word List (AWL) and non-AWL content words in applied linguistics research papers. English for Specific Purposes, 28(1), 33-41. Doi: 10.1016/j.esp.2008.08.003

Yang, M. N. (2015). A nursing academic word list. English for Specific Purposes 37(1) pp. 27-38. Doi: $10.1016 /$ j.esp.2014.05.003

Yılmaz, E. (2014). Temel Dil Bilgisi Terimleri Sözlüğü [Basic Grammar Dictionary]. Pegem Akademi.

Zucker, T. A., Carlo M. S. Montroy, J. J. and Landry, S. H. (2021). Pilot test of the Hablemos Juntos Tier 2 academic language curriculumfor Spanish-speaking preschoolers. Early Childhood Research Quarterly, 55. 179-192. Doi: 10.1016/j.ecresq.2020.11.009 


\section{Appendices}

Appendix A. The Academic Word List in Social Science

\begin{tabular}{|c|c|c|c|c|}
\hline yapıl- & 176 & bulunabilme & 18 & iliş̧kili \\
\hline bulun- & 131 & sözlü & 18 & kullanabilme \\
\hline tarihî & 100 & aktör & 17 & kurumsal \\
\hline edil- & 76 & amaçlı & 17 & numaralı \\
\hline işaretle- & 71 & araştır- & 17 & reklamcılık \\
\hline alın- & 67 & askerî & 17 & ahlâki \\
\hline getiril- & 60 & kurul- & 17 & basit \\
\hline başla- & 58 & propaganda & 17 & başlıklı \\
\hline ipucu & 56 & anlat- & 16 & beklen- \\
\hline görül- & 55 & m.ö & 16 & belirgin \\
\hline tartı̧s- & 51 & entelektüel & 15 & esaslı \\
\hline tartışma & 51 & kit & 15 & filozof \\
\hline bırakıl- & 50 & davranışsal & 14 & hristiyanlık \\
\hline maliye & 50 & endüstriyel & 14 & karşılanma \\
\hline yaz1l- & 50 & arkeolog & 13 & kurulu \\
\hline ayrıl- & 45 & hitap & 13 & örgütsel \\
\hline kavrayabilme & 45 & mevcut & 13 & popüler \\
\hline literatür & 45 & sosyokültürel & 13 & say1l- \\
\hline dayan- & 39 & zitlik & 13 & tasnif \\
\hline satın al- & 39 & dinsel & 12 & tramvay \\
\hline ebedî & 35 & katılımeı & 12 & tüzel \\
\hline ayırt & 34 & odaklan- & 12 & video \\
\hline robot & 34 & oluşturabilme & 12 & yakalı \\
\hline isten- & 32 & sunul- & 12 & adli \\
\hline belirt- & 31 & uygulan- & 12 & ağırlıklı \\
\hline madenî & 31 & adlandırıl- & 11 & as1l \\
\hline dikkate al- & 30 & düşünsel & 11 & bağlantılı \\
\hline eşleştir- & 29 & genişletebilme & 11 & duyul- \\
\hline tatmin & 29 & gösteril- & 11 & geçebilme \\
\hline oluştur- & 28 & hazırlan- & 11 & hristiyan \\
\hline üretil- & 28 & insanoğlu & 11 & ibadet \\
\hline arkeolojik & 27 & kazanım & 11 & ihlâl \\
\hline mitolojik & 27 & yaşan- & 11 & istenil- \\
\hline felsefi & 24 & erdemli & 10 & kapsamlı \\
\hline türlü & 24 & geliştiril- & 10 & kıymetli \\
\hline incelen- & 23 & kronolojik & 10 & oluşturma \\
\hline okuyabilme & 23 & örf & 10 & sosyolojik \\
\hline belirlen- & 22 & özetleyebilme & 10 & sözde \\
\hline ilâhiyat & 22 & söylen- & 10 & süreli \\
\hline kamusal & 22 & tanımlayıcı & 10 & şüphesiz \\
\hline meydana gel- & 22 & temsili & 10 & yaratma \\
\hline e-tandem & 22 & bilin- & 9 & yürütül- \\
\hline karşılaş- & 20 & blog & 9 & aktarabilme \\
\hline anlayabilme & 19 & düşünül- & 9 & anlaşı1- \\
\hline finansal & 19 & faydalı & 9 & anlattl- \\
\hline
\end{tabular}




\begin{tabular}{|c|c|c|c|c|}
\hline artırılma & 6 & seramik & 5 & sebebiyle \\
\hline başlan- & 6 & sistemli & 5 & seçmeli \\
\hline belirlenme & 6 & söz dizimsel & 5 & sekreterlik \\
\hline belirtil- & 6 & temelli & 5 & siniflandirıcı \\
\hline binlerce & 6 & toplan- & 5 & sigortacilık \\
\hline denil- & 6 & yorumlanma & 5 & sözel \\
\hline eğlendirme & 6 & ak1lsal & 4 & sözleşmeci \\
\hline fail & 6 & algilan- & 4 & şan \\
\hline fişleme & 6 & amaçlan- & 4 & tahkim \\
\hline hizlica & 6 & anayasal & 4 & tahsis \\
\hline icra & 6 & asgari & 4 & takdirde \\
\hline ilgilendir- & 6 & ayrintılı & 4 & tamamla- \\
\hline iliş- & 6 & başarısız & 4 & teamül \\
\hline itibarıyla & 6 & benimse- & 4 & tekrarlan- \\
\hline kazandir- & 6 & benzeri & 4 & uşak \\
\hline kökenli & 6 & birleşmiş & 4 & vaat \\
\hline nitelendiril- & 6 & bulunma & 4 & web \\
\hline partner & 6 & coğrafi & 4 & yayımlan- \\
\hline sürdür- & 6 & çeşitlilik & 4 & âdeta \\
\hline vazgeçil- & 6 & çevrilme & 4 & adil \\
\hline yansitabilme & 6 & değerlendiril- & 4 & aktar1l- \\
\hline yapılma & 6 & değerlendirilme & 4 & algılayış \\
\hline alanyazın & 5 & devamsızlık & 4 & algisal \\
\hline azalma & 5 & eklektisizm & 4 & alışılmış \\
\hline başarılı & 5 & farkındalık & 4 & anlamlandırabilme \\
\hline başlı & 5 & geçir- & 4 & aş- \\
\hline bekçi & 5 & hukuksal & 4 & aşamalı \\
\hline bilinçli & 5 & iradi & 4 & bak1l- \\
\hline dakikalık & 5 & islami & 4 & çözümleyebilme \\
\hline derviş & 5 & iyileştir- & 4 & değerli \\
\hline devletlerarası & 5 & katılabilme & 4 & denizcilik \\
\hline dilbilimci & 5 & k1l- & 4 & detaylı \\
\hline epigrafi & 5 & kiyas & 4 & dilsel \\
\hline fen & 5 & küçümse- & 4 & diplomasi \\
\hline finanse et- & 5 & mahrum & 4 & diplomatik \\
\hline getirme & 5 & mahsur & 4 & dizayn \\
\hline girebilme & 5 & mahsus & 4 & durul- \\
\hline ilişkilendiril- & 5 & mahzur & 4 & duyuşsal \\
\hline izah & 5 & mevhum & 4 & dünyevi \\
\hline izlenme & 5 & modernite & 4 & düzenlen- \\
\hline konul- & 5 & motive & 4 & elektrikli \\
\hline kuralcı & 5 & mütekamil & 4 & eleştirel \\
\hline kütüphane & 5 & nitelikli & 4 & enerjik \\
\hline manevi & 5 & ruhsal & 4 & erdemsiz \\
\hline mecbur & 5 & sade & 4 & format \\
\hline neden-sonuç & 5 & sanatsal & 4 & geçersizlik \\
\hline nihai & 5 & sarf et- & 4 & geçin- \\
\hline ölçekli & 5 & saylli & 4 & geçirme \\
\hline
\end{tabular}




$\begin{array}{llllll}\text { gelişmişlik } & 3 & \text { makroekonomik } & 3 & \text { staj } & 3 \\ \text { gereksiz } & 3 & \text { maruz } & 3 & \text { sürül- } & 3 \\ \text { gerektir- } & 3 & \text { masraf } & 3 & \text { tanrısal } & 3 \\ \text { hareketli } & 3 & \text { mefhum } & 3 & \text { tarafsız } & 3 \\ \text { hazırlayabilme } & 3 & \text { mesleki } & 3 & \text { telif } & 3 \\ \text { icat } & 3 & \text { milyon } & 3 & \text { telsiz } & 3 \\ \text { ideolojik } & 3 & \text { modernleşme } & 3 & \text { teoloji } & 3 \\ \text { iletil- } & 3 & \text { muhtelif } & 3 & \text { tesir } & 3 \\ \text { imparator } & 3 & \text { münhasır } & 3 & \text { teşkil } & 3 \\ \text { inceleyebilme } & 3 & \text { müracaat } & 3 & \text { tıbbi } & 3 \\ \text { islamiyet } & 3 & \text { mütekamillik } & 3 & \text { tonoz } & 3 \\ \text { istatistiksel } & 3 & \text { niceliksel } & 3 & \text { unutul- } & 3 \\ \text { istikrarlı } & 3 & \text { nüfuz } & 3 & \text { ustalık } & 3 \\ \text { işlen- } & 3 & \text { öncelikli } & 3 & \text { uyarınca } & 3 \\ \text { ithal } & 3 & \text { örgütlenme } & 3 & \text { uyulma } & 3 \\ \text { kablolu } & 3 & \text { peşin } & 3 & \text { vagon } & 3 \\ \text { karlı } & 3 & \text { plaka } & 3 & \text { vazife } & 3 \\ \text { karmaş̧ıklaş- } & 3 & \text { planlı } & 3 & \text { vergileme } & 3 \\ \text { kastedil- } & 3 & \text { politikacı } & 3 & \text { vergilendirilme } & 3 \\ \text { kazanma } & 3 & \text { sağlanma } & 3 & \text { yaşat- } & 3 \\ \text { kestirme } & 3 & \text { sanıl- } & 3 & \text { yayınlanma } & 3 \\ \text { kolayca } & 3 & \text { satım } & 3 & \text { yenilikçi } & 3 \\ \text { koordine } & 3 & \text { seçil- } & 3 & \text { yorumlan- } & 3 \\ \text { kripto } & 3 & \text { serbestçe } & 3 & \text { yönetsel } & 3 \\ \text { kumaş } & 3 & \text { sirasılyla } & 3 & \text { yüzlerce } & 3 \\ \text { kurulma } & 3 & \text { sofist } & 3 & \text { meydana çıkar- } & 1 \\ \text { lisansüstü } & 3 & \text { solu- } & 3 & & \end{array}$

Appendix B. The Academic Word List in Engineering-Health Sciences

$\begin{array}{llllll}\text { kullanıl- } & 286 & \text { belirt- } & 44 & \text { sağlan- } & 23 \\ \text { çalışma } & 270 & \text { edebilme } & 43 & \text { üretil- } & 22 \\ \text { bulun- } & 237 & \text { kavrayabilme } & 42 & \text { yazabilme } & 22 \\ \text { fen } & 217 & \text { tartı̧- } & 40 & \text { yenilen- } & 21 \\ \text { veril- } & 180 & \text { anlayabilme } & 39 & \text { başlıklı } & 20 \\ \text { yapıl- } & 150 & \text { dikkate al- } & 35 & \text { endüstriyel } & 20 \\ \text { elde et- } & 90 & \text { yapabilme } & 34 & \text { kazanım } & 20 \\ \text { sosyal } & 84 & \text { alın- } & 32 & \text { meydana gel- } & 20 \\ \text { işaretle- } & 80 & \text { uygun } & 31 & \text { bilin- } & 19 \\ \text { literatür } & 77 & \text { tarihi } & 30 & \text { den- } & 19 \\ \text { mühendislik } & 70 & \text { anlamlı } & 29 & \text { elektrikli } & 19 \\ \text { görül- } & 59 & \text { birakıl- } & 29 & \text { geliştiril- } & 19 \\ \text { robotik } & 58 & \text { cevapla- } & 28 & \text { yazıl- } & 19 \\ \text { ayırt } & 57 & \text { resmî } & 28 & \text { kullanılma } & 18 \\ \text { robot } & 56 & \text { dayan- } & 26 & \text { zararlı } & 18 \\ \text { getirebilme } & 46 & \text { kirlilik } & 26 & \text { saptan- } & 17 \\ \text { isten- } & 44 & \text { okuyabilme } & 24 & \text { tanımlan- } & 16\end{array}$




\begin{tabular}{|c|c|c|c|c|}
\hline tıbbi & 16 & kökenli & 9 & yansitabilme \\
\hline adlandırıl- & 15 & numaralı & 9 & aktarabilme \\
\hline bulaş- & 15 & oluşturul- & 9 & bildiril- \\
\hline gösteril- & 15 & tesir & 9 & detaylı \\
\hline kullanabilme & 15 & yetiştiril- & 9 & farklılaş- \\
\hline entelektüel & 14 & birleşmiş & 8 & fizikçi \\
\hline geçebilme & 14 & çeşitlilik & 8 & hassas \\
\hline ilişkili & 14 & düzenlen- & 8 & kalp-damar \\
\hline zamanlı & 14 & katılabilme & 8 & kanserli \\
\hline geliştirilme & 13 & milyon & 8 & memnuniyet \\
\hline hazırlan- & 13 & oluşturma & 8 & müşahede \\
\hline maruz & 13 & som & 8 & OK uygulaması \\
\hline anlatil- & 12 & sosyo-kültürel & 8 & önle- \\
\hline aziz & 12 & sözlü & 8 & özelleşmiş \\
\hline çevresel & 12 & algilan- & 7 & rehabilite \\
\hline düşünül- & 12 & anlat- & 7 & say1l- \\
\hline fişleme & 12 & ayrıntıl1 & 7 & sıkça \\
\hline glutensiz & 12 & belirleyebilme & 7 & siniflandırılma \\
\hline güvenli & 12 & benzeri & 7 & yararlan- \\
\hline kronolojik & 12 & değerli & 7 & yayımlan- \\
\hline odaklan- & 12 & entegre & 7 & yoluyla \\
\hline özetle- & 12 & güvenilir & 7 & yönetil- \\
\hline ruhsal & 12 & psikolojik & 7 & alınma \\
\hline türlü & 12 & robot-cerrah & 7 & bakıl- \\
\hline beklen- & 11 & sözde & 7 & barındır- \\
\hline belirlenme & 11 & tamir & 7 & belirlen- \\
\hline boyutlu & 11 & yataklı & 7 & bertaraf \\
\hline denil- & 11 & zitlik & 7 & bileşenli \\
\hline genişletebilme & 11 & anlamlandirabilme & 6 & çaplı \\
\hline oluşturabilme & 11 & anlaş1- & 6 & elektriksel \\
\hline sıklıkla & 11 & artıril- & 6 & file \\
\hline tanımlayıcı & 11 & atıl- & 6 & hasarlı \\
\hline yeterli & 11 & başlan- & 6 & hitap \\
\hline adlı & 10 & belirtil- & 6 & hücreli \\
\hline alanyazın & 10 & binlerce & 6 & ihtiva \\
\hline batırma & 10 & değerlendirilme & 6 & ilik \\
\hline derviş & 10 & getirme & 6 & kapsamlı \\
\hline girebilme & 10 & gösterebilme & 6 & kesitsel \\
\hline incelenme & 10 & hedeflen- & 6 & mahrum \\
\hline kütüphane & 10 & islah & 6 & milyar \\
\hline nakil & 10 & imal & 6 & nitelikli \\
\hline tanın- & 10 & izafiyet & 6 & nörogelişimsel \\
\hline aktarılma & 9 & lisansüstü & 6 & nükleer \\
\hline amaçlan- & 9 & ölçekli & 6 & önlenme \\
\hline amaçlı & 9 & saptanma & 6 & rahatlıkla \\
\hline ciddi & 9 & sebep & 6 & sosyo-ekonomik \\
\hline dağıtık & 9 & süreli & 6 & sözel \\
\hline kıyasla- & 9 & uğraş- & 6 & suni \\
\hline
\end{tabular}




\begin{tabular}{llllll} 
sunul- & 4 & eleştirel & 3 & kolayca & 3 \\
tamamla- & 4 & etkilen- & 3 & konulu & 3 \\
tarihsel & 4 & etkinli & 3 & koşullandırma & 3 \\
telif & 4 & faydalı & 3 & mahsul & 3 \\
toplumcu & 4 & feza & 3 & mesnetsiz & 3 \\
tüketilme & 4 & fren & 3 & milyonlarca & 3 \\
yaralı & 4 & gelirli & 3 & muhtemelen & 3 \\
asgari & 3 & gerçekleştiril- & 3 & odaklı & 3 \\
asılma & 3 & gönderilme & 3 & okun- & 3 \\
ateşli & 3 & görülme & 3 & pdf & 3 \\
atıl & 3 & gözlen- & 3 & psikiyatrik & 3 \\
azalma & 3 & güneşli & 3 & sedye & 3 \\
azaltılma & 3 & haberdar & 3 & siralan- & 3 \\
azami & 3 & hatalı & 3 & silindirik & 3 \\
başlatıl- & 3 & hazırlayabilme & 3 & spss & 3 \\
batırıl- & 3 & hazırlıklı & 3 & staj & 3 \\
bilgilendirici & 3 & ikna edici & 3 & şarj & 3 \\
bilimci & 3 & ilerledikçe & 3 & şimdiki & 3 \\
birleştirilme & 3 & imzala- & 3 & tahrip & 3 \\
bulutlu & 3 & imzalan- & 3 & tȩskil & 3 \\
çevrele- & 3 & incelen- & 3 & tolere et- & 3 \\
çıkarılma & 3 & isimli & 3 & uygulan- & 3 \\
çizili & 3 & istatistiki & 3 & video & 3 \\
çözümleyebilme & 3 & istenil- & 3 & yapıcı & 3 \\
dakikalık & 3 & kanamalı & 3 & yararlı \\
damit- & 3 & kandır- & 3 & yaşan- & 3 \\
değerlendiril- & 3 & katil & 3 & yemle- & 3 \\
denizcilik & 3 & kavlak & 3 & yetiştirmecilik & 3 \\
desteklenme & 3 & kayıpsız & 3 & yöneticilik & 3 \\
dilsel & 3 & kazandır- & 3 & yürütül- & 3 \\
duyul- & 3 & kilolu & 3 & bertaraf et- & 2 \\
eklemle- & 3 & kireçleştirme & 3 & emin ol- & 2 \\
& & & & & 3 \\
\hline
\end{tabular}

